\title{
PERSONAL HYGIENE SAAT MENSTRUASI PADA SISWI YANG TINGGAL DIASRAMA KARTINI SAMARINDA
}

\author{
Maria Floriana Ping \\ Jurusan Keperawatan, STIKES Dirgahayu Samarinda \\ Jl. Pasundan Nomor 21 Kelurahan Jawa Kecamatan Samarinda Ulu \\ Kota Samarinda Kalimantan Timur Kode Pos 75122 \\ pingmaria@yahoo.com
}

\begin{abstract}
ABSTRAK
Masa remaja merupakan periode terjadinya pertumbuhan dan perkembangan yang pesat baik secara fisik, psikologis maupun intelektual. Sifat khas remaja mempunyai rasa keingintahuan yang besar, menyukai petualangan dan tantangan serta cenderung berani menanggung risiko atas perbuatannya tanpa didahului oleh pertimbangan yang matang. Sifat dan prilaku berisiko pada remaja tersebut memerlukan ketersediaan pelayanan kesehatan peduli remaja yang dapat memenuhi kebutuhan kesehatan remaja termasuk pelayanan untuk kesehatan reproduksi. Penelitian ini bertujuan untuk mengetahui personal hygiene saat menstruasi pada siswi yang tinggal di Asrama Kartini Samarinda. Penelitian ini merupakan penelitian deskritif kuantitatif melibatkan 49 responden yang merupakan siswi SMP dan SMA yang tinggal di Asrama Kartini Samarinda yang telah mengalami menstruasi. Dari penelitian ini ditemukan bahwa, kelompok umur dengan responden terbanyak berada pada kelompok umur 16 tahun yaitu sebanyak 17 responden (34,7\%), siswi yang tinggal di Asrama Kartini Samarinda mayoritas memiliki pengetahuan yang cukup tentang menstruasi yaitu sebanyak 34 siswi $(65,3 \%)$, tidak pernah mandi 3 kali sehari saat menstruasi yaitu sebanyak 36 siswi (73,5\%). sering mencuci rambut (keramas) 3 kali dalam seminggu saat menstruasi yaitu sebanyak 27 siswi $(55,1 \%)$ tidak pernah mencuci tangan sebelum dan sesudah memakai pembalut yaitu sebanyak 28 siswi (57,1\%). tidak pernah membersihkan alat kelamin/ kemaluan dengan air bersih dari arah depan ke belakang yaitu sebanyak 38 siswi $(77,6 \%)$ selalu membersihkan kemaluan dengan tisu saja tanpa di basuh dengan air sebelumnya yaitu sebanyak $46(93,9 \%)$. tidak pernah mengganti pembalut 3-4 kali sehari yaitu sebanyak 40 siswi $(81,6 \%)$ tidak pernah membungkus pembalut dengan kertas/plastik sebelum dibuang ke tempat sampah yaitu sebanyak 36 siswi $(73,5 \%)$ tidak pernah mengetahui akibat yang ditimbulkan apabila tidak hygiene yaitu sebanyak 23 siswi $(46,9 \%)$.
\end{abstract}

Kata Kunci: Remaja, Menstruasi, Personal Hygiene 


\begin{abstract}
Teenager is a period of rapid growth and development both physically, psychologically and intellectually. Teenagers have a great sense of curiosity, love adventure and challenge and tend to dare to risk the action without preceded by careful consideration. The risky nature and behavior of adolescents require the availability of adolescent health care services that meet youth health needs including services for reproductive health. This study aims to find out the personal hygiene during menstruation to girls living in the Kartini Samarinda Dormitory. This research is a quantitative descriptive study involving 49 respondents who are high school and junior high school students who live in Kartini Samarinda Dormitory who have experienced menstruation. From this study found that the age group with the most respondents are in the age group of 16 years, 17 respondents (34.7\%), the students living in Sartinda Kartini Dormitory have a sufficient knowledge about menstruation, ie 34 students $(65,3 \%)$, never bathing 3 times a day during menstruation as many as 36 female students $(73.5 \%)$. often wash hair (shampoo) 3 times a week during menstruation as many as 27 female students $(55.1 \%)$ never wash hands before and after wearing pads that is as much as 28 female students $(57.1 \%)$. never cleaned the genitals with clean water from the front to the back that is 38 students $(77.6 \%)$ always clean the genitals with tissues alone without the basuh with the previous water that is as much as $46(93.9 \%)$. never changing pads 3-4 times a day as many as 40 students (81.6\%) never wrap the pads with paper / plastic before disposal into the trash that is as much as 36 female students (73.5\%) never know the consequences if not hygiene that is as much as 23 students $(46,9 \%)$.
\end{abstract}

Keywords: Teenager, menstruation, personal hygiene 


\section{PENDAHULUAN}

Menurut WHO, remaja adalah penduduk dalam rentang usia 10-19 tahun,menurut Peraturan Menteri Kesehatan RI Nomor 25 tahun 2014, remaja adalah penduduk dalam rentang usia 10-18 tahun dan menurut BAdan Kependudukan dan Keluarga Berencana (BKKBN) rentang usia remaja adalah 10-24 tahun dan belum menikah. Jumlah kelompok usia 10-19 tahun di Indonesia menurut sensus penduduk 2010 sebanyak 43,5 juta atau sekitar $18 \%$ dari jumlah penduduk. Didunia diperkirakan kelompok remaja berjumlah 1,2 milyar atau $18 \%$ dari jumlah penduduk dunia (WHO, 2014).

Masa remaja merupakan periode terjadinya pertumbuhan dan perkembangan yang pesat baik secara fisik, psikologis maupun intelektual. Sifat khas remaja mempunyai rasa keingintahuan yang besar, menyukai petualangan dan tantangan serta cenderung berani menanggung risiko atas perbuatannya tanpa didahului oleh pertimbangan yang matang. Sifat dan prilaku berisiko pada remaja tersebut memerlukan ketersediaan pelayanan kesehatan peduli remaja yang dapat memenuhi kebutuhan kesehatan remaja termasuk pelayanan untuk kesehatan reproduksi (Infodatin, 2015).

Kesehatan reproduksi adalah keadaan sehat secara fisik, mental dan social secara utuh, tidak sematamata bebas dari penyakit atau kecacatan yang berkaitan dengan sistem, fungsi dan proses reproduksi. Menurut International
Conference Population and Development (ICPD)tahun 1994 di Kairo, ruang lingkup pelayanan kesehatan reproduksi mencakup kesehatan reproduksi remaja (Infodatin, 2015).

Hasil SDKI 2012 KRR menunjukkan bahwa pengetahuan remaja tentang kesehatan reproduksi belum memadai yang dapat dilihat dengan hanya $35,3 \%$ remaja perempuan dan $31,2 \%$ remaja lakilaki usia 15-19 tahun mengetahui bahwa perempuan dapat hamil dengan satu kali berhubungan seksual. Begitu pula gejala PMS kurang diketahui oleh remaja. Informasi tentang HIV relative lebih banyak diterima oleh remaja, meskipun hanya $9,9 \%$ remaja perempuan dan $10,6 \%$ laki-laki memiliki pengetahuan komprehensif mengenai HIV-AIDS. Tempat pelayanan remaja juga belum banyak diketahui oleh remaja (Infodatin, 2012).

Remaja putri yang sudah matang alat reproduksinya maupun hormone-hormon dalam tubuhnya akan mengalami menstruasi. Menstruasi adalah keluarnya darah dari kemaluan setiap bulan akibat meluruhnya dinding rahim (endometrium) yang mengandung pembuluh darah karena sel telur (ovum) tidak dibuahi (Pudiastuti, 2012). Pembuluh darah dalam rahim sangat mudah terinfeksi ketika menstruasi karena kuman mudah amsuk dan menimbulkan penyakit pada saluran reproduksi (Kusmiran, 2012). Infeksi dan amsalah vagina dipengaruhi oleh infeksi bakteri, 
virus, jamur dan parasit (Pudiastuti, 2012). Selain itu, terjadi iritasi pada vagina akibat bahan kimia atau fisik (seperti sabun, spermisida, pembalut dan lain-lain), alergi dan dermatitis kontak serta adanya penyebab lain seperti polip servikalis/neoplasma (Davey, 2005). Keluhan pada organ reproduksi yang sering terjadi adalah pruritus vulva yaitu ditandai adanya sensai gatal parah dari alat kelamin perempuan (Misery, 2010).

Ketidakadekuatan hygiene merupakan salah satu factor risiko terjadinya kanker vulva (Davey, 2005). Selain itu, amsalah hygiene juga merupakan factor risiko terjadinya infertilitas sekunder pada wanita. Masalah hygiene ini melipiti penggunaan pembalut yang tidak higienis saat menstruasi dimana remaja menggunakan kain yang dipakai ulang setelah dikeringkan, bahkan mereka mengeringkannya ditempat tersembunyi dan tidak terkena sinar matahari. Tindakan ini berisiko terhadap tumbuhnya mikroba dan larva serangga sehingga mengakibatkan vagina berbau busuk atau terjadi keputihan (Ali, 2007).

\section{METODE}

Desain deskriptif kuantitatif dengan analisa univariat pada tiap variable pada penelitian ini, dengan menggunakan teknik total sampling pada populasi dengan sampel yang sesuai dengan criteria inklusi yaitu: remaja puti yang tinggal di Asrama Kartini dan sudah mengalami menstruasi.

Peneliti juga berpegang pada etika penelitian yaitu informed consent, kerahasiaan, keanoniman, keadilan, kemanfaatan, dan kejujuran. Analisa data menggunakan SPSS 22, variabel yang dianalisa secara univariat meliputi pengetahuan. Dalam penelitian yang akan dilakukan dengan menggunakan univariat yaitu distribusi pengetahuan dan perilaku personal hygiene saat menstruasi pada siswi-siswi yang tinggal di Asrama Kartini Samarinda.

HASIL

Analisa Univariat

Tabel 1.1 Usia Responden

\begin{tabular}{ccc}
\hline \multirow{2}{*}{ Umur (Tahun) } & \multicolumn{2}{c}{ Remaja Putri } \\
\cline { 2 - 3 } & $\begin{array}{c}\text { Jumlah } \\
(\mathrm{n})\end{array}$ & $\begin{array}{c}\text { Persentase } \\
(\%)\end{array}$ \\
\hline 12 tahun & 1 & 2.0 \\
13 tahun & 3 & 6.1 \\
14 tahun & 7 & 14.3 \\
15 tahun & 7 & 14.3 \\
16 tahun & 17 & 34.7 \\
17 tahun & 12 & 24.5 \\
18 tahun & 2 & 4.1 \\
\hline Total & 49 & 100 \\
\hline
\end{tabular}

Tabel menunjukkan bahwa dari 49 responden, kelompok umur dengan responden terbanyak berada pada kelompok umur 16 tahun yaitu sebanyak 17 responden (34,7\%), sedangkan kelompok umur dengan responden yang paling sedikit jumlahnya adalah kelompok umur 12 tahun yaitu sebanyak 1 responden $(2,0 \%)$.

Menurut Notoatmodjo (2007) semakin tinggi usia seseorang, semakin berkembang pula daya tangkap dan pola pikirnya, sehingga pengetahuan yang diterimapun semakin baik dan mudah diterima. Menurut Refliana (2005) semakin dewasa umur seseorang, tingkat pengetahuan seseorang akan lebih matang, dan lebih baik dalam berpikir maupun bertindak. 
Tabel 1.2 Tingkat Pengetahuan

\begin{tabular}{ccccc}
\hline Pengetahuan & & & $\mathrm{N}(\%)$ & \\
\cline { 2 - 5 } Tentang Menstruasi & $\mathrm{S}$ & $\mathrm{S}$ & $\mathrm{K}$ & $\mathrm{T}$ \\
\hline $\begin{array}{c}\text { Saya mandi 3 kali } \\
\text { sehari saat }\end{array}$ & 0 & 3 & $10(20.4)$ & 36 \\
$\quad$ menstruasi & & $(6.1)$ & & $(73.5)$ \\
$\begin{array}{c}\text { Saya mencuci } \\
\text { rambut (keramas) } 3\end{array}$ & 5 & 27 & $7(14.3)$ & $10(20.4)$ \\
kali dalam seminggu \\
saat menstruasi \\
$\quad$ Kurang
\end{tabular}

Berdasarkan tabel diatas, dapat diketahui gambaran pengetahuan siswi yang tinggal di Asrama Kartini Samarinda tentang menstruasi, siswi yang berpengetahuan baik adalah sebanyak 9 siswi $(18,4 \%)$, berpengetahuan cukup 34 siswi $(65,3 \%)$ dan yang berpengetahuan kurang 8 siswi $(16,3 \%)$. Dari data diatas dapat disimpulkan bahwa siswi yang tinggal di Asrama Kartini Samarinda mayoritas memiliki pengetahuan yang cukup tentang menstruasi yaitu sebanyak 34 siswi $(65,3 \%)$.

Berdasarkan tabel diatas, dapat diketahui gambaran pengetahuan siswi yang tinggal di Asrama Kartini
Samarinda tentang menstruasi, siswi yang berpengetahuan baik adalah sebanyak 9 siswi $(18,4 \%)$, berpengetahuan cukup 34 siswi $(65,3 \%)$ dan yang berpengetahuan kurang 8 siswi $(16,3 \%)$. Dari data diatas dapat disimpulkan bahwa siswi yang tinggal di Asrama Kartini Samarinda mayoritas memiliki pengetahuan yang cukup tentang menstruasi yaitu sebanyak 34 siswi $(65,3 \%)$.

Berdasarkan tabel diatas ditemukan bahwa mayoritas siswi yang tinggal di Asrama Kartini Samarinda tidak pernah mandi 3 kali sehari saat menstruasi yaitu sebanyak 36 siswi (73,5\%), dan tidak ada yang selalu mandi 3 kali sehari saat menstruasi $(0 \%)$.

Berdasarkan tabel diatas ditemukan bahwa mayoritas siswi yang tinggal di Asrama Kartini Samarinda sering mencuci rambut (keramas) 3 kali dalam seminggu saat menstruasi yaitu sebanyak 27 siswi $(55,1 \%)$, siswi yang tidak pernah mencuci rambut (keramas) 3 kali dalam seminggu saat menstruasi sebanyak $10 \quad(20,4 \%)$, siswi yang kadang-kadang mencuci rambut (keramas) 3 kali dalam seminggu saat menstruasi sebanyak $7(14,3 \%)$ dan hanya 5 siswi $(10,2 \%)$ siswi yang selalu mencuci rambut (keramas) 3 kali dalam seminggu saat menstruasi. Berdasarkan tabel diatas mayoritas siswi yang tinggal di Asrama Kartini tidak pernah mencuci tangan sebelum dan sesudah memakai pembalut yaitu sebanyak 28 siswi $(57,1 \%)$, sebanyak 13 siswi (26,5\%) sering mencuci tangan sebelum dan sesudah memakai pembalut, sebanyak 6 siswi $(12,2 \%)$ kadang-kadang mencuci tangan sebelum dan sesudah memakai pembalut dan hanya $2(4,1 \%)$ siswi saja yang selalu mencuci tangan sebelum dan sesudah memakai pembalut.

Berdasarkan tabel diatas mayoritas siswi yang tinggal di Asrama Kartini Samarinda tidak pernah membersihkan 
alat kelamin/ kemaluan dengan air bersih dari arah depan ke belakang yaitu sebanyak 38 siswi $(77,6 \%), 10$ siswi $\quad(20,4 \%) \quad$ kadang-kadang membersihkan alat kelamin/ kemaluan dengan air bersih dari arah depan ke belakang, hanya 1 siswi $(2,0 \%)$ yang sering membersihkan alat kelamin/ kemaluan dengan air bersih dari arah depan ke belakang, dan tidak ada siswi (0\%) yang selalu membersihkan alat kelamin/ kemaluan dengan air bersih dari arah depan ke belakang.

Berdasarkan tabel diatas mayoritas siswi yang tinggal di Asrama Kartini Samarinda selalu membersihkan kemaluan dengan tisu saja tanpa di basuh dengan air sebelumnya yaitu sebanyak 46 (93,9\%), sebanyak 3 $(6,1 \%)$ siswi sering membersihkan kemaluan dengan tisu saja tanpa di basuh dengan air sebelumnya, dan tidak ada (0\%) siswi yang kadangkadang bahkan tidak pernah membersihkan kemaluan dengan tisu saja tanpa di basuh dengan air sebelumnya.

Berdasarkan tabel diatas, mayoritas siswi yang tinggal di Asrama Kartini Samarinda tidak pernah mengganti pembalut 3-4 kali sehari yaitu sebanyak 40 siswi $(81,6 \%), 8(16,3 \%)$ siswi kadang-kadang mengganti pembalut 3-4 kali sehari, hanya 1 $(2,0 \%)$ siswi yang sering mengganti pembalut 3-4 kali sehari, dan tidak ada $(0 \%)$ siswi yang selalu mengganti pembalut 3-4 kali sehari.

Berdasarkan tabel diatas ditemukan bahwa mayoritas siswi yang tinggal di Asrama Kartini Samarinda tidak pernah segera mengganti celana dalam yang terkena darah saat menstruasi yaitu sebanyak 32 siswi $(65,3 \%)$, sebanyak 13 siswi (26,5\%) kadang-kadang segera mengganti celana dalam yang terkena darah saat menstruasi, hanya 4 siswi $(8,2 \%)$ yang sering segera mengganti celana dalam yang terkena darah saat menstruasi dan tidak ada siswi (0\%) yang segera mengganti celana dalam yang terkena darah saat menstruasi. Berdasarkan tabel diatas ditemukan bahwa mayoritas siswi yang tinggal di Asrama Kartini Samarinda tidak pernah membungkus pembalut dengan kertas/palstik sebelum dibuang ke tempat sampah yaitu sebanyak 36 siswi $(73,5 \%)$, sebanyak 8 siswi $(16,3 \%)$ kadang-kadang membungkus pembalut dengan kertas/palstik sebelum dibuang ke tempat sampah, 5 siswi $(10,2 \%)$ sering membungkus pembalut dengan kertas/palstik sebelum dibuang ke tempat sampah dan tidak ada siswi $(0 \%)$ yang selalu membungkus pembalut dengan kertas/palstik sebelum dibuang ke tempat sampah.

Berdasarkan tabel diatas ditemukan bahwa mayoritas siswi yang tinggal di Asrama Kartini Samarinda sering memakai celana dalam yang tidak menyerap keringat yaitu sebanyak 23 siswi $(46,9 \%)$, sebanyak 12 siswi $(24,5 \%)$ selalu memakai celana dalam yang tidak menyerap keringat, 10 siswi $(20,4 \%)$ kadang-kadang memakai celana dalam yang tidak menyerap keringat dan hanya 4 siswi $(8,2 \%)$ yang tidak pernah memakai celana dalam yang tidak menyerap keringat.

Berdasarkan tabel diatas ditemukan data bahwa mayoritas siswi yang tinggal di Asrama Kartini Samarinda sering memakai celana dalam yang menyerap keringat, sebanyak 16 siswi $(32,7 \%)$ tidak pernah memakai celana dalam yang menyerap keringat, sebanyak 14 siswi $\quad(28,6 \%) \quad$ kadang-kadang memakai celana dalam yang menyerap keringat dan tidak ada siswi (0\%) yang selalu memakai celana dalam yang menyerap keringat.

Berdasarkan tabel diatas ditemukan data bahwa mayoritas siswi yang tinggal di Asrama Kartini tidak pernah mengetahui akibat yang ditimbulkan apabila tidak hygiene yaitu sebanyak 23 siswi (46,9\%), sebanyak 12 siswi 
$(24,5 \%) \quad$ yang kadang-kadang mengetahui akibat yang ditimbulkan apabila tidak hygiene, sebanyak 9 siswi $(18,4 \%)$ sering mengetahui akibat yang ditimbulkan apabila tidak hygiene, dan hanya 5 siswi $(10,2 \%)$ yang selalu mengetahui akibat yang ditimbulkan apabila tidak hygiene.

Berdasarkan tabel diatas ditemukan data bahwa mayoritas siswi yang tinggal di Asrama Kartini Samarinda sering curhat dengan teman teman apabila ada keluhan yang terjadi pada dirinya, yaitu sebanyak 19 siswi $(38,8 \%)$, sebanyak 14 siswi $(28,6)$ tidak pernah curhat dengan teman teman apabila ada keluhan yang terjadi pada dirinya, sebanyak 11 siswi $(22,4)$ kadang-kadang curhat dengan teman teman apabila ada keluhan yang terjadi pada dirinya, dan hanya 5 siswi $(10,2 \%)$ yang selalu curhat dengan teman teman apabila ada keluhan yang terjadi pada dirinya.

\section{PEMBAHASAN}

Menurut Notoadmodjo (2010), pengetahuan atau Kognitif merupakan domain yang sangat penting untuk terbentuknya tindakan seseorang (ovent behavior). Berdasarkan pengalaman dan penelitian ternyata perilaku yang didasari oleh pengetahuan akan lebih langgeng dari pada perilaku yang tidak didasari oleh pengetahuan. Mengingat kembali terhadap suatu yang spesifik dari seluruh badan yang telah dipelajari atau yang telah diterima, oleh sebab itu tahu ini merupakan tingkat pengetahuan yang paling rendah.

Menurut Notoatmodjo (2007) terdapat beberapa factor yang mempengaruhi pengetahuan, salah satunya adalah informasi, semakin banyak informasi yang diterima maka semakin banyak pula pengetahuan yang dimiliki. Sesorang siswi SMA sangat mungkin memiliki pengetahuan mengenai menstruasi, karena telah melewati bangku SD dan SMP dan seringnya kegiatan penyuluhan mengenai kesehatan reproduksi dilaksanakan pada siswi-siswi sekolah.

Berdasarkan hasil penelitian Kusmiran (2012) sebagian besar remaja putri mandi lebih dari 2 kali sehari saat menstruasi, hal ini dilakukan agar badan tetap segar dan bebas dari bau badan akibat keringat yang diproduksi secara berlebih saat menstruasi. Lawan, Yusuf \& Musa (2010) dalam penelitiannya juga menyatakan bahwa remaja putri menambah frekuensi mandinya saat menstruasi sebanyak 3 sampai 4 kali per hari.

Menurut penelitian yang dilakukan oleh Kusmiran (2012) sebagian besar remaja putri keramas setiap 2 hari sekali saat menstruasi, hal ini dilakukan agar badan tetap segar dan bebas dari bau badan akibat keringat yang diproduksi secara berlebih saat menstruasi. Menurut Pujiastuti (2010) dalam Sulastri (2017), kesalahan yang sering dilakukan saat pemakaian pembalut adalah membuka dan memasang pembalut tanpa mencuci tangan terlebih dahulu. Cara membersihkan daerah kewanitaan yang terbaik adalah dengan membasuhnya dari arah depan ke belakang (dari vagina kea rah anus) bukan sebaliknya, karena apabila berbalik arah, maka kuman dari anus akan masuk kedalam vagina (Varney, 2007).

Pembalut selama menstruasi harus diganti secara teratur 4-5 kali atau setiap setelah mandi, buang air kecil dan buang air besar. Apabila permukaan pembalut telah ada gumpalan darah, segera ganti pembalut, karena gumpalan darah tersebut merupakan tempat yang sangat baik untuk perkembangan jamur (Varney, 2007 dalam Sulastri, 2017).

Menurut Ahira dan Wijayanti (2009) salah satu perilaku positif saat menstruasi yaitu mengganti pembalut 
paling sedikit (3-4) kali sehari, pemakaian pembalut tidak boleh lebih dari enam jam dan diganti sesering mungkin bila sudah penuh dengan darah.

Pengetahuan personal hygiene sangat penting karena pengetahuan yang baik dapat meningkatkan kesehatan. Disebagian masyarakat misalnya menstruasi dianggap darah kotor sehingga seorang wanita harus diasingkan dan menjalani aktivitas harian di dalam rumah adat khusus untuk wanita yang tengah menstruasi. Pada kondisi sakit kemampuan merawat diri berkurang dan perlu bantuan untuk melakukannya (Sulastri, 2017).

Dampak tidak menjaga personal hygiene saat menstruasi terhadap kesehatan reproduksi wanita banyak terjadi gangguan kesehatan yang diderita seseorang karena tidak terpeliharanya kebersihan perorangan dengan baik. Antara lain gangguan intergritas kulit, infeksi pada mata dan telinga dan gangguan fisik pada kuku. Dampak psiko-sosial, masalah sosial yang berhubungan dengan personal hygiene adalah gangguan kebutuhan rasa nyaman (Tarwoto dan Wartonah, 2010). Timbul infeksi pada genetalia, infeksi ini timbul disesebabkan oleh buruknya kebersihan di area vagina. Infeksi vagina yang umum terjadi, seperti vaginitis bacterial, trichomonas vaginalis, dan kandidiasis vulvovaginal dapat terjadi sepanjang kehidupan wanita. Vaginitis (peradangan pada vagina) adalah salah satu yang paling dikeluhkan wanita. Gejala seperti pruritus vulvae, iritasi, inflamasi, sekresi vaginal, dan rasa perih, biasanya diakibatkan oleh salah satu organisme berikut: Candida albican, Trichomonas vaginalis, dan Gardnerella vaginalis. Sekitar $25 \%$ dari kasus yang ada disebabkan oleh C. Albican dan T. vaginalis, dan sisanya oleh $\mathrm{G}$. Vaginalis (Baradero, 2007; Bobak, 2008).

\section{KESIMPULAN DAN SARAN}

\section{Kesimpulan}

Berdasarkan hasil penelitian yang dilakukan didapatkan hasil sebagai berikut:

1. Mayoritas usia remaja putri di Asrama Kartini adalah 17 tahun (34.7\%).

2. Mayoritas tingkat pengetahuan remaja putri di Asrama Kartini tentang pengetahuan adalah cukup yakni sebanyak 34 siswi (65.3\%).

3. Mayoritas remaja putri di Asrama Kartini tidak pernah mandi 3 kali sehari saat menstruasi yaitu sebanyak 36 siswi (73.5\%).

4. Mayoritas siswi yang tinggal di Asrama Kartini Samarinda sering mencuci rambut (keramas) 3 kali dalam seminggu saat menstruasi yaitu sebanyak 27 siswi $(55,1 \%)$.

5. Mayoritas siswi yang tinggal di Asrama Kartini tidak pernah mencuci tangan sebelum dan sesudah memakai pembalut yaitu sebanyak 28 siswi $(57,1 \%)$.

6. Mayoritas siswi yang tinggal di Asrama Kartini Samarinda tidak pernah membersihkan alat kelamin/ kemaluan dengan air bersih dari arah depan ke belakang yaitu sebanyak 38 siswi $(77,6 \%)$.

7. Mayoritas siswi yang tinggal di Asrama Kartini Samarinda selalu membersihkan kemaluan dengan tisu saja tanpa di basuh dengan air sebelumnya yaitu sebanyak 46 $(93,9 \%)$.

8. Mayoritas siswi yang tinggal di Asrama Kartini Samarinda yang mengganti pembalut 3-4 kali sehari yaitu sebanyak 40 siswi $(81,6 \%)$. 
9. Bahwa mayoritas siswi yang tinggal di Asrama Kartini Samarinda tidak pernah segera mengganti celana dalam yang terkena darah saat menstruasi yaitu sebanyak 32 siswi $(65,3 \%)$.

10. Mayoritas siswi yang tinggal di Asrama Kartini Samarinda tidak pernah membungkus pembalut dengan kertas/palstik sebelum dibuang ke tempat sampah yaitu sebanyak 36 siswi $(73,5 \%)$.

11. Mayoritas siswi yang tinggal di Asrama Kartini Samarinda sering memakai celana dalam yang tidak menyerap keringat yaitu sebanyak 23 siswi $(46,9 \%)$.

12. Mayoritas siswi yang tinggal di Asrama Kartini Samarinda sering memakai celana dalam yang menyerap keringat, sebanyak 16 siswi $(32,7 \%)$.

13. Mayoritas siswi yang tinggal di Asrama Kartini tidak pernah mengetahui akibat yang ditimbulkan apabila tidak hygiene yaitu sebanyak 23 siswi (46,9\%).

14. Mayoritas siswi yang tinggal di Asrama Kartini Samarinda sering curhat dengan teman teman apabila ada keluhan yang terjadi pada dirinya, yaitu sebanyak 19 siswi $(38,8 \%)$.

\section{Saran}

Remaja putri adalah para calon ibu bagi para penerus bangsa Indonesia, pentingnya pengetahuan mereka tentang menjaga alat reproduksi yang sehat adalah yang terpenting yang dapat dimulai saat mereka telah mengalami menstruasi.

Hasil pengetahuan ini menjadi dasar bagi peneliti untuk melaksanakan kegiatan yang berkelanjutan bagi remaja putri yang tinggal di Asrama Kartini, dan juga menjadi rekomendasi bagi para peneliti lainnya.

\section{DAFTAR PUSTAKA}

Arikunto, S. 2010. Prosedur Penelitian. Jakarta: PT Rineka Cipta

Bobak, Lowdermilk \& Jensen. 2008. Buku Ajar Keperawatan Maternitas. Jakarta: EGC

Kusmiran, Eny. Kesehatan Reproduksi Remaja dan Remaja. Jakarta: Salemba Medika

Notoatmodjo, S. 2007. Promosi Kesehatan dan Ilmu Perilaku. Jakarta : Rineka Cipta

Notoadmojo, S. 2010. Metodologi Penelitian Kesehatan. Jakarta : PT Rineka Cipta

Pudjiastuti, Ratna Dewi. 3 Fase Penting Pada Wanita (Menarche, Menstruasi, dan Menopause). 2012

Proverawati, Atika. "Menarche Menstruasi Pertama Penuh Makna". Yogyakarta: Nuha Medika, 2009.

Prawirohardjo, Sarwono. "Ilmu Kebidanan”. Jakarta: PT. Bina Pustaka Sarwono Prawirohardjo,2010.

Refliana, Iriana. LIPI (Lembaga Ilmu Pengetahuan Indonesia) Komunika-warta ilmiah populerkomunikasi dalam pembangunan. ISSN 01262491. Vol 8, no. 220015

Sulastri, Yulianti. 2017. Gambaran Personal Hygiene Saat Menstruasi Pada Siswi SMP Islam Ungaran Kabupaten Semarang. Semarang: UNW

Thakre, Subhash B et al. Menstruasi Hygiene: knowledge and Practice among Adolescent School Girls of Saoner, Nagpur District. Journal of Clinical and Diagnostik 
Research. 2011 October, vol5(5): 1027-1033

Varney, H. 2007. Buku Ajar Asuhan Kebidanan Edisi 4. Jakarta ; EGC

Yusuf, Syamsu. 2012. Psikologi Perkembangan Anak \& Remaja. Bandung: PT. Remaja Rosdakarya 